\title{
Survey of the Literature on Safety of Residential Chimneys and Fireplaces
}

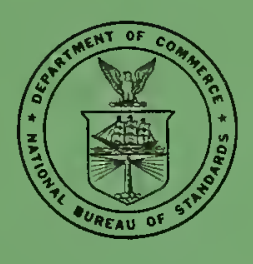

United States Department of Commerce National Bureau of Standards

Miscellaneous Publication 252 


\section{THE NATIONAL BUREAU OF STANDARDS}

\section{Functions and Activities}

The functions of the National Bureau of Standards include the development and maintenance of the national standards of measurement and the provision of means and methods for making measure ments consistent with these standards; the determination of physical constants and properties of materials; the development of methods and instruments for testing materials, devices, and structurcs; advisory services to government agencies on scientific and technical problems; invention and devclopment of devices to serve special needs of the Government; and the development of standard practices, codes, and specifications, including assistance to industry, business and consumers in the development and acceptance of commercial standards and simplified trade practice recommendations. The work includes basic and applied research, development, engineering, instrumentation, testing, evaluation, calibration services, and various consultation and information services. Research projects are also performed for other government agencies when the work relates to and supplements the basic program of the Bureau or when the Bureau's unique competence is re quired. The scope of activities is suggested by the listing of divisions and sections on the inside of the back cover.

\section{Publications}

The results of the Bureau's research are published either in the Bureau's own series of publications or in the journals of professional and scientific societies. The Bureau itself publishes three periodicals available from the Government Printing Office: The Journal of Research, published in four separate sections, presents complete scientific and technical papers; the Technical News Bulletin presents summary and preliminary reports on work in progress; and Central Radio Propagation Laboratory Ionospheric Predictions provides data for determining the best frequencies to use for radio communications throughout the world. There are also seven series of nonperiodical publications: Monographs, Applied Mathematics Series, Handbooks, Miscellaneous Publications, Technical Notes, Commercial Sta Jards, and Simplified Practice Recommendations.

A complete listing of the Bureau's publications can be found in National Bureau of Standards Circular 460, Publications of the National Bureau of Standards, 1901 to June 1947 ( $\$ 1.25)$, and the Supplement to National Bureau of Standards Circular 460, July 1947 to June 1957 (\$1.50), and Mis cellaneous Publication 240, July 1957 to June 1960 (includes Titles of Papers Published in Uutside Journals 1950 to 1959) (\$2.25); available from the Superintendent of Docunients, Government Printing Office, Washington, D.C., 20102. 


\title{
Survey of Literature on the Safety of Residential Chimneys and Fireplaces
}

\author{
Harry Shoub
}

Conducted Under the Technical Studies Program of the Federal Housing Administration

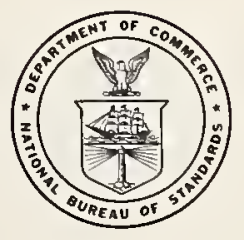

National Bureau of Standards Miscellaneous Publication 252

Issued December 17, 1963 
Library of Congress Catalog Card Number: 63-62134 


\title{
Survey of Literature on the Safety of Residential Chimneys and Fireplaces ${ }^{1}$
}

\author{
Harry Shoub
}

\begin{abstract}
A search was made of recent technical literature on chimneys and fireplaces to determine what information was available on questions concerning their safety from fire hazard. The survey covered types of construction and materials proposed or currently in use with several types of fuel. The reports included investigations of heat transmission through chimney and fireplace walls, the effects of thermal shock on flue materials, and the required spacing of combustibles from the heated walls. The bibliography presented contains brief reviews of some of the works.
\end{abstract}

\section{Introduction}

Chimneys and fireplaces in some form, ranging from crude to elaborate, have been used since very early times, but questions concerning their design and construction, particularly with regard to features relating to fire safety, continue to be raised. As a preliminary to proposed technical investigations, it appeared that a literature survey of published and unpublished data available to the National Bureau of Standards might prove fruitful in providing information in some areas of concern. While the primary objective was to present works relating to problems of fire hazard, collateral information on associated subjects of interest has been briefly included.

Although several highly significant earlier references are included, the bibliographic study was confined mainly to those papers issued since about 1950. It was thought that these would most likely yield useful data which were not yet widely disseminated, and would also give an indication of the scope of work in progress or recently completed.

The bibliography of works on chimneys and fireplaces is presented in two sections, the first containing those papers available for review, for which a brief summary or indication of the contents is given, the other listing works which were not readily available under the limitations of search set for this project, but which were believed to contain information of interest. Since they are closely associated, papers on both chimneys and fireplaces are presented together in reverse chronological order.

Mention must be made of some early works on fireplaces and chimneys. Three are of considerable significance, probably the most remarkable being Count Rumford's "Chimney Fireplaces," which appeared in 1796. This book reports the results of scientific investigation, and contains rules for the construction of fireplaces that are valid and in use today. Benjamin Franklin contributed to the science of domestic heating with the publication, in 1745, of his "Papers on Philosophical Subjects." Even earlier was the work of M. Gauger, "La Mécanique du Feu" ("The Mechanics of Fire") published in France in 1709. An English translation was made by J. T. Desaguliers in 1715 . Works such as these may well be the basis of the "conclusions based on long experience" often found in papers relating to heating problems.

\section{Bibliography of Publications Reviewed and Abstracted}

1. Fact-Finding Report on Masonry Fireplaces, for Federal Housing Administration, Underwriters' Laboratories, Inc. File USNC 24, June 29, 1962, and October 18, 1962: Tests were made on a masonry fireplace to determine what temperature would be obtained on the masonry surfaces and on combustible materials adjacent to or in contact with the masonry. Fuels in the tests of the June report were wood brands (input $32 \mathrm{lb} / \mathrm{hr}$ ), charcoal $(28 \mathrm{lb} / \mathrm{hr})$, and $\operatorname{logs}(26 \mathrm{lb} / \mathrm{hr})$. The tests were discontinued before equilibrium temperatures were reached, as the temperature of combustible materials, especially those at the back wall, exceeded established maximum safe limits. The

1 This paper was prepared under the sponsorship of the Federal Housing Administration. report is well supplied with plans of the test structure, and is documented with extensive test data. The October report presents data on additional tests with charcoal and logs with fuel rates for both at approximately 10 and $20 \mathrm{lb} / \mathrm{hr}$. Except for the test with the larger quantity of charcoal, firings were continued for 12 hr. A comparison is made of temperatures of combustibles in contact with the masonry and at $3 / 4$ in. spacing for the two firing rates, and for 4-in.- and 8-in.-thick masonry walls.

2. Residential Chimneys of Non-Traditional Design, Institute TNO voor Bouwmaterialen en Bouwconstructies (Netherlands) 1961-1: Temperature difference between the outer and inner wall 
surfaces of a concrete chimney with round flue $12 \mathrm{~cm}$ in dianleter depends on the wall thickness. With the heat transmission of the concrete not higher than $0.4 \mathrm{kcal} / \mathrm{meter}$ hour ${ }^{\circ} \mathrm{C}$ and a flue gas temperature of 600 degrees $\mathrm{C}$ above the ambient, this difference amounts to 146 degrees $C$ for a wall thickness of $6 \mathrm{~cm}$ and 95 degrees $\mathrm{C}$ for $8 \mathrm{~cm}$. Some of the advantages of concrete chimneys with ceramic flue liner over the traditional brick chimney are fewer cracks and lower temperatures on the outer covering. Unlined concrete chimneys are characterized by low resistance to deterioration from heat and to flue gas attack. Recommendations in the paper are for the use of horizontal reinforcing in unlined climneys, and for concrete with low water-cement ratio and quartz-free porous aggregate.

3. Contribution to the Study of the Behavior Under Heat of Concretes for Chimney Flues, M. L. Boy, Centre Scientifique et Technique du Bâtiment (France), No. 51, Cahier 408, August 1961: Concretes resistant to heat effects and thermal shock for use in chimney flues are described. Temperature gradients in chimney walls are great enough to engender high thermal stresses. Concrete flue liners should not be subjected to thermal shock until several months after fabrication. It is important to cloose an aggregate with a low coefficient of thermal expansion.

4. Flues (Approval of New Materials and NonTraditional Methods of Construction), Cahiers du C.S.T.B. (France), No. 49, F.4, 1961, 392: Approval tests are described for various proprietary concrete chimney flue blocks, mainly with pozzuolanic aggregate. Cracking of some flues occurred from tinermal shock. Determinations were made of air permeability coefficients of the blocks.

5. Station for Tests of Chimney Flues, Centre Scientifique et Technique du Bâtiment (France), No. 47, Cahier 379, December 1960, p. 14: Tests were made of the effect of thermal shock from flue gasses at 400 and $500{ }^{\circ} \mathrm{C}$ on concrete block chimney flues. Gas permeability measurements were made before and after the blocks were subjected to the thermal shock.

6. Chimney flues of Concrete Block, Centre Scientifique et Technique du Bâtiment (France), No. 44, Cahier 348, June 1960: Tests were made of lightweight concrete chimney block units, some with coverings of 1 or $2 \mathrm{~cm}$ of plaster. Temperature data are given for the interior and exterior faces of the flue for various flue gas temperatures, and the effect of heat on various concretes is described. Fuels were coal, wood, and oil.

7. Chimneys, Tests on Masonry Residential Type, National Board of Fire Underwriters Special Interest Bulletin No. 14, May 1960: Tests were conducted at Underwriters' Laboratories, Inc., on a standard (National Building Code) masonry chinney. Excessive heat buildup noted on ceilings placed in contact with the chimney indicated the necessity of providing an open airspace between the chimney wall and combustible material. At 2 in. from the chimney, temperatures were lower on sheet enclosure material than on wood studs, probably because of the larger radiating surface area of the shect. Increasing the chimney wall thickness by 4 in. where the end of a wood girder was in contact prevented a hazardous temperature rise on the wood.

8. Performance of Type B Gas Vents for GasFired Appliances, L. M. Kline and H. Witte, Underwriters' Laboratories, Inc., Bulletin of Research No. 51, May 1959: 'Tests were made to determine the temperatures of flue gases passing through different vent systems. Heat sources were a central furnace, water heater, floor furnace, unit heater, and room heater. Four types of vent pipes were used: double wall with 1/2- and $3_{4}^{\prime}-i n$. airspace, single wall, and asbestos-cement, mostly of 3- and 5-in. diameter. Data are shown for temperatures of flue gases at inlet of draft hoods and vents, and temperature rises on vent pipe walls and walls of vent pipe enclosures. Least heat transmission was noted with double-wall metal pipe with $1 / 2$-in. airspace. A separate section of the report (Part II, by A. F. Matson, R. E. Dufour, and J. F. Breen) contains a survey of the ignition of wood exposed at elevated temperatures for long periods. It was concluded from the evidence that such exposure should be limited to a maximum temperature of 90 degrees $\mathrm{F}$ above room temperature.

9. Testing of a Chimney, Gote Larsson, Statens Provningsanstalt (Sweden), Meddelande 125, 1959: Tests with brick chimneys indicate that combustible materials will be ignited if maintained in continued contact with a chimney of $12 \mathrm{~cm}$ wall thickness if the flue gas temperatures are $400{ }^{\circ} \mathrm{C}$. It appears that ignition of combustibles near chimneys occurs because of unsatisfactory chimney insulation rather than from lack of tightness of the chimney walls. Restraint of a chimney during a chimney fire can cause cracks to be formed through the entire structure. Chimney brickwork should not be used to support building members unless the chimney has an internal, independent flue.

10. Temperature of the Wall behind a BackBoiler Fire, L. L. Fox and D. Whittaker, J. Institution of Heating and Ventilating Engineers, London, Vol. 26, 1958, pp. 80-85: Model bylaws state that the thickness of the rear wall of a fireplace recess shall be not less than 4 in. for external wall, or $8 \frac{1}{2}$ in. for internal. On a bare 9 -in. brick back wall, the highest temperature on the outside surface was $130^{\circ} \mathrm{F}$ with coke fuel and 
$150{ }^{\circ} \mathrm{F}$ with coal. Burning house coal at the greatest possible rate for $12 \mathrm{hr}$, a boiler fire produced a temperature of $175^{\circ} \mathrm{F}$ on a bare outside wall 9 in. thick, and $305^{\circ} \mathrm{F}$ on a $4 \frac{1}{2}$-in. wall. With a 1-in. board cemented to the brick, temperatures of 265 and $570^{\circ} \mathrm{F}$ were attained on the brick for the two wall thicknesses.

11. An Analysis of Survey Information on Chimney Fires, Joint Fire Research Organization (U.K.), May 195\%: As coal is the most widely used of all fuels in the United Kingdom, there is little available evidence to indicate the contribution of other fuels to the incidence of chimney fires. The paper suggests that in view of this widespread use of coal for domestic heating, frequent cleaning of the lower part of a chimney may be an important factor in preventing fires.

12. Chimney Stacks Made of Precast Concrete Units, G. Heinicke, Betonsteinzeitung Wiesbaden, Vol. 22, No. 12, Dec. 1956, pp. 718-726: Requirements for chimney construction of concrete block are described, as well as the technical and economic advantages of the use of this material. Methods of framing roof members around a chimney are illustrated.

13. Residential Fireplace Design, Structural Clay Products Institute, Technical Notes on Brick and Tile Construction, Vol. 6, No. 10, Oct. 1955: The paper includes a description of fireplace parts, National Building Codes recommendations, and a table of flue sizes for different sizes and types (single face, two face, etc.) of fireplaces.

14. Some Measurement of Temperatures of Metal Flues of Domestic Heating Appliances, L. L. Fox and D. Whittaker, J. Institution of Heating and Ventilating Engineers, London, Vol. 23, 1955, pp. 183-192: Three types of small solidfuel appliances were tested in normal operation with coal and coke fuels. Temperatures are given for flue gases and surfaces of sheet metal flue pipe, with higher temperatures recorded for coal. In a closed fire with solid fuel, considerable and rapid changes in temperature are possible. There is some mention of the fire hazard to timbers adjacent to flues.

15. Thermal Insulation and Fire Protection of Small Chimneys, Paul Becker, Ingeniøren, Copenhagen, Vol. 64, No. 42, 1955, pp. 827-831: Chimneys of various masonry constructions, times of curing, flue diameters, and outer protections were tested. Fuels were anthracite, coke, lignite, peat, wood, oil, and city gas. The paper gives heat transmission data, and shows examples of good and bad practice in chimney design.

16. Tests on Types of Chimneys With Regard to Fire Resistance, Gerhard Hansen, Ingeniøren, Copenhagen, Vol. 64, No. 42, 1955, pp. 832-833: Chimneys of lightweight concretes (pumice, cinder, etc.) were tested with flue gas temperatures to $1000^{\circ} \mathrm{C}$ using a small heating' stove source. The formation of dangerous cracks is described. The performance of a conventional brick chimney was used as reference in evaluating the results.

17. ACI Standard Specification for the Design and Construction of Reinforced Concrete Chimneys (ACI 505-54), American Concrete Institute $J$. 26 (1), 1954-55, pp. 1-48: Formulas are given for determining temperature gradients through concrete chimney shells.

18. The Heating of Panels by Flue Pipes, D. J Lawson, L. L. Fox, C. T. Webster, Department of Scientific and Industrial Research, Fire Offices Committee (U.K.), Fire Research Special Report No. 1, Her Majesty's Stationery Office, 1952: Temperature rise on a vertical panel near a cylindrical radiating surface was computed. An asbestos shield proved effective in reducing the temperature of the panel, with a greater advantage deriving from separation of the shield and the panel. Separations greater than $1 / 2$ in., however", gave little additional temperature reduction. Theoretical and experimental derivations were made for heat transfer from flue pipes not enclosed or covered. The tests were made with solid fuels.

19. Residential Chimney Design and Construction, Structural Clay Products Institute, Technical Notes on Brick and Tile Construction, Vol. 3, No. 1, Jan. 1952: Tests were made of brick chimneys 4 in. thick with standard 8- by 8-in. flue liners. In a chimney where the flue lining sections were not cemented and a space was left between the lining and the brick, the airspace appeared to have no effect on the operation, and no appreciable insulating value. It was considered preferable to bond the liner sections and fill the space between liner and brick solidly with cement mortar on the basis of the greater strength of this construction and its ability to stay in place when cracked. Standard construction and clearances from combustibles (NBFU) are recommended.

20. The Construction of Central Heating Flues, M. Bergstrom, Teknisk Tidskrift, Stockholm, 80 (13), 1950, pp. 288-94: Temperatures to 1300 ${ }^{\circ} \mathrm{C}$ were observed in chimney soot fires. Tests were made of chimneys having inner and outer shells of brickwork with an intermediate layer of mineral wool. Concrete outer shells approximately 4 in. thick were also used. Inner lining should be able to move freely when expanded by heat. Minor cracking of inner shell was not found to be important, provided outer shell remains intact.

21. The Problem of the Flue From the Fireman's Point of View, I. Stromdahl, Teknisk Tidskrift, Stockholm, 80 (13), 1950, pp. 283-286: Tempera- 
ture rise in flue fires may be very rapid, especially with wood fuel. In a test, a temperature of 900 ${ }^{\circ} \mathrm{C}$ was observed in $3 \mathrm{~min}, 1300^{\circ}$ ('in $15 \mathrm{~min}$ after start.

22. Fires in Flues From the Point of View of Insurance Companies, A. Sylven, Teknisk Tidskrift, Stochholm, 80 (13), 1950, pp. 286-288: Fires of short duration seldom cause damage to a well-constructed brick chimney, even if very high temperatures occur. The inner brickwork of a double-shelled brick chimmey with mineral wool filler withstood 10 soot fires with temperatures reaching to $1400{ }^{\circ} \mathrm{C}$ before destruction.

23. Fire Hazard Tests With Masonry Chimneys, Nolan D. Mitchell, NFPA Quarterly, Vol. 43, No. 2, Oct. 1949: Tests were made of 21 different masonry chimneys constructed of brick, tile, or concrete block units, either unlined or with cernmic or vitreous enameled steel liners. Some concrete block units had integrally cast liners. Fuels were coal, wood, and gas. Unlined chimneys present greater fire hazards than do lined ones. Round liners appear to have some advantage over rectangular ones. Liners should not be rigidly fixed to the chimney wall. Units with integrally cast liners developed cracks through both the liner and outer wall. The space between chimney wall and wood framing should be left unfilled. Mineral wool fills between joists and chimneys have in some cases caused ignition of the wood. Wood plaster grounds should be removed, and staying at floor or roof level should be limited to contact with flooring or sheathing not more than $1 \frac{1}{2}$ in. from corners of chimney.

24. Performance of Masonry Chimneys for Houses, R. K. Thulman, Technical Paper No. 13, Housing and Home Finance Agency, Aug. 1949: The criterion of safety to combustible materials adjacent to a chimney is established as 90 degrees $\mathrm{F}$ temperature rise on the combustible with flue gas temperature of $1000^{\circ} \mathrm{F}$ for $5 \mathrm{hr}$ and $1400^{\circ} \mathrm{F}$ for $1 \mathrm{hr}$. A substantial portion of the heat in the flue gases is lost through the masonry in the area adjacent to the entrance of the breeching, probably because of turbulence. Introducing air into the breeching reduces the temperature of flue gases. Chimneys with mortar lining only appear to be responsible for more fires than those with ceramic flues. Insulation between flue lining and outer shell reduces temperatures on the outside wall. The paper recommends that contacts between combustible construction and masonry surfaces not already prohibited by building codes, should be banned. Data are included for tenperatures of flue gases, brick surfaces of lined and unlined chimneys, and of wood in contact with masonry and also at 2-in. spacing from the masonry.

25. Clearances and Insulation of Heating Appliances, John A. Neele, Underwriters' Labora- tories, Inc., Bulletin of Research No. 27, June 1945: The heating of adjacent woodwork by stoves and smokepipes is described. Safe maximum temperature for long-continued exposure of wood was established as 90 degrees $F$ above room temperature. In order not to exceed this maximum lise, a clearance of $7 \mathrm{in}$. would have to be provided between a wood panel and a sinokepipe at $450^{\circ} \mathrm{F}$. Thoroughly dried and slightly scorched wood panels were found to develop higher temperatures on the surface than they did when new.

\section{Temperatures Developed in Chimneys for} Low Cost Houses, NBS Technical News Bulletin No. 328, Aug. 1944, p. 62: 'To establish performance requirements for tests of light-weight, prefabricated chimneys, tests were conducted with lined and unlined chimneys having 4in.-thick brick walls. In the surrounding structure, floor joists were framed 2 in. away from the chimney surface, but edges of floorboards and nailing strips were placed in contact. After approximately $13 \mathrm{hr}$ for the lined chimneys, and slightly less time for the unlined, and with flue gas temperatures of $1100^{\circ} \mathrm{F}$ and $900^{\circ} \mathrm{F}$, respectively, hazardous temperature conditions were created on surrounding wood.

27. Observed Performance of Some Experimental Chimneys, R. S. Dill, P. R. Achenbach, J. T. Duck, Heating, Piping and Air Conditioning, Vol.14, Apr. 1942, pp. 252-256: 'Tests were made on two experimental, residential-type chimneys operating at various stack heights, gas flows, and inlet temperatures. Data are given for temperature gradients at different levels in the chimney, which were of brick masonry with ceramic flue liner.

28. Fire Hazard of Domestic Heating Installations, G. Q. Voigt, Bureau of Standards Research Paper RP 596, Sept. 1933: 'Tests were made of domestic stores and furnaces and their pipes. Temperature rise was determined on partitions, ceilings, and floors, as well as the effect of some protective materials. Ignition of wood could occur from short-time exposure at temperatures of 250 to $300{ }^{\circ} \mathrm{C}$, or from long exposure at $150{ }^{\circ} \mathrm{C}$. Temperatures frequently exceeding $125^{\circ} \mathrm{C}$ should be avoided, but $150{ }^{\circ} \mathrm{C}$ may be tolerated occasionally. Uninsulated smoke pipes passing through combustible partitions require 4 in. of vented airspace at the sides, or may be insulated with 2 in. of mineral wool. Stoves having the fire box or ash pit directly on the floor can transmit temperatures capable of igniting wood through a 4 -in.-thick brick base. With a 5 -in. airspace between stove and floor, the floor should be further protected with $1 / 4$-in. asbestos or similar material under sheet metal. The possiblity of igniting: wood forms left under brick or concrete arches supporting fireplaces is indicated. 
29. Recommended Minimum Requirements for Small Dwelling Construction, Bureau of Standards Building and Housing Publication No. 18, 1932, pp. 19-22 and 78-89: Designs are given for chimneys and fireplaces, and methods of framing combustible members around them. Ceramic flue linings are preferable to parged brickwork. For fireplaces, good draft design requires an effective area of flue of $1 / 12$ of the area of the fireplace opening.

30. Prefabricated Metal Chimneys, National Bureau of Standards, Fire Research Section, unpublished reports to Federal Public Housing Authority, District of Columbia Alley Dwelling Authority, and others, 1941-45: Tests were made with prefabricated porcelain-enameled metal chimneys for solid or liquid fuel furnaces in war-emergency housing. A limiting temperature rise of $375^{\circ} \mathrm{F}$ on the outer surface of the chimney was established for a flue gas temperature of $1000{ }^{\circ} \mathrm{F}$. Under this condition, combustible framing and wood spaced 2 in. or more away from the chimney was considered safe. Satisfactory insulation of the chimneys was obtained with asbestos paper plies totaling about $1 \frac{3 / 4}{\mathrm{in}}$. in thickness and having a combustible content not exceeding 5 percent. Some asbestos-cement pipe covering's were also found to be capable of reducing heat transmission to the extent required for safety to nearby combustibles.

\section{Selected Publications Not Reviewed}

31. The Fire Proof Chimney, Bayerischen Versicherungskammer (Germany), 1959.

32. Chimney Fires, Fire, London, 1958, 51 (639) $197,200$.

33. Chimneys and Fire Protection, A. H. Bergquist, Byggmastaren, Stockholm, 1958, 134 $77-80$.

34. Modern Flue and Chimney Construction, Bldg. Mat., London, 1958, 18 (2), 69-70.

35. Experimental Observations Concerning Cracks in Flues, Claudon and Tirel, Ann. Inst. Bâtiment, Paris, 1958, 11 (121), 40-52.

36. Thermal Stresses in Flues, J. Tirel, Ann. Inst. Bâtiment, Paris, 1958, 11 (121), 28-39.

37. Gas Flues, Archt. (Build.) J., London 1958, 127 (3295), 624-634.

38. The Design of Domestic Open Fires, D. K. Darby, Plumber, London, 1958, 80 (949) $45-50$; (950) 43-44.

39. Structural Fire Protection, Fortschritte u. Forschungen im Bauwesen, Reihe D, Heft 2y Franckh'sche Verlagshandlung, Stuttgart, 1957. (Fire resistance of flues of standard masonry and of lightweight conweight concrete castings.)

40. Domestic Flues, P. Becher, Industries Thermiques, Paris, 1957 (11), 655-665.

41. Materials for Flues, A. Claudon, Industries Thermiques, Paris, 1957 (11), 666-688.

42. Theory of the Construction of Chimney Flues, R. Cadiergues, Industries Thermiques, Paris, 1957 (11), 689-701.

43. The Cracking of Flues, Centre Scientifique et Technique du Bâtiment (France), Cahier 238, 1957.

44. Space Heating and Associated Fire Hazards, Booklet No. 33, Fire Protection Assn. (U.K.), London, 1957.

45. Oil Fired Domestic Boilers and Air Heaters for Hot Water Supply and Space Heating: Safety Recommendations, Booklet No. 31, Fire Protection Association (U.K.), London, 1957.
46. Maximum Temperatures Attained in Chimney Flues, A. Claudon, Industries Thermiques, Paris, 1957, 3 (1), 21-40.

47. Lightweight Concrete Shaped Blocks of up to $700 \mathrm{~cm}^{2}$ Section, Standard DIN 18150, Deutscher Normenausschuss, Berlin, 1956.

48. Fire Tests on Domestic Chimneys, H. Seekamp and K. Mohler, Verl. von Wilm. Ernst u. Sohn, Berlin, 1956.

49. Aluminum-Sheet Chimneys, Light Metals Bull., London, 1956, 18 (8), 316.

50. Flue Pipes and Combustible Materials, Fire Prot. Assn. J., 1956, (33), 207.

51. Flue Piping Causes Fire, Fire Protection (Rev.), London, 1956, 19 (185), 178.

52. Chimney Fires, Prot. Civile, Paris, 1956, (23), 46-47

53. Temperatures on a Wood Ceiling about a Furnace Plenum, R. Ditsworth, Heat. Air Condit. Contract., Tarrytown, N.Y., 1955, 2\%, (2) (Issue 715), 31-37.

54. The Protection of Floors under Fireplaces, F Mayer, Osterr. Feuerwehr, Vienna, 1955, 9 (1), 8-9.

55. Tentative Code of Minimum Obligatory Conditions for the Fixing of Fire-Grates and Associated Conduits, Ann. Inst. Bâtiment, Paris, 1955, 8 (94) Supp.

56. Design of Heating and Ventilating Systems, F. W. Hutchinson, The Industrial Press, New York, 1955.

57. A Guide to Current Practice, Inst. of Heat. Vent. Engrs., London, 1955.

58. Asbestos-Cement Flue Pipes and Fittings, Light Quality, BS 567, British Standards Institution, London, 1954.

59. Domestic Fireplaces and Chimmeys, Commonwealth Experimental Bldg. Sta., Dept. of Works and Housing, Australia, Notes on the Science of Bldg. No. SB 31, Chatswood, N.S.W., 1954.

60. Prefabrication in Traditional House Building I, N. S. Pippard and W. G. Buckle, Prefab- 
rication, London, 1954,1 (7), 15-18 (prcfab. brick chimney stack).

61. Firc Incidents With Fireplaces, Flue Pipes and Climneys, R. Qucstcr, Osterr. Feuerwehr, Vienna, 1953, $y$ (3), 47-7, 49 .

62. The Hazard of Domestic Fire, J. F. Fry, J. Roy. Inst. Brit. Archt., London, 1953, 61 (1), 18-20.

63. Fire 'Tests on Chimneys, S. Ausobsky, Osterr. Feuerwelır, Vienna, 1952, 6 (12), 234-236.

64. Structural 'Timber under the Hearth, Fire Prot. Assn. J., London, 1952, (19), 307-308.

65. Flue Pipes and Hearths, Norsk Brannvern Forening, Oslo, Sept. 1952.

66. New Documents on Flue Construction, Ribaud, Puteaux, Fournol and Gouffé, Centre Scientifique et Technique du Bâtiment (France), Cahier 111, 1951.

67. Regulations and Instructions on the Venting of Domestic Gas Heathing Appliances, O. Rösler, Gas, Wasser, Warme, Vienna 1951, 5 (1), 6-16.

68. Domestic Chimneys, P. Becher, Statens Byggeforskningsinstitut, Studie No.6, Copenhagen, 1951.

69. Fire Resistance Tests on Chimney Blocks and Glass Panels, K. Walz and J. Strey,
Tonindustric Zeitung, Goslar (Ger.), 1951, $75(13 / 14), 203-208$.

70. Flucs for Domestic Appliances Burning Solid Fuel, Brit. Stds. Inst., Council of Codes of Practice for Bldgs., CP 131.101, London, 1951.

71. Domestic Hearths. Fires Due to Defects, Fire Prot. Assn. J., London, 1951, (12) Jan. 9-11.

72. Three Hazards That Need Watching, Doors, Flues, Water Heaters, Fire Protection, London, 1951, 14 (130), 317-318.

73. Smoky Chimneys, Bldg. Research Sta. Digest No. 18, HMSO, London, May 1950. (Design of fireplaces and flues.)

74. Chimney Constructions and Dimensions of Bricks, Virtala and Koskela, Valton Teknillinen Tutkimuslaitos, Tiedoitus 40 and 43, Helsinki, 1947.

75. Drawings of the Principles of Construction of the Swedish Fire Prevention Assn., Svenska Brandskyddsforeningen, Stockholm, 1946 (fireplaces and flues).

76. Precast Concrete Flues, Concrete Building, London, 1946, 21 (8), 103-107.

77. Fire Hazards of Chimneys and Flues, Technical Information Sheet 1001, Fire Protection Assn., London.

\section{Information and Conclusions From Reference Sources}

An examination of the material in the reviewed publications indicates that information is available on several aspects of the problem of fire safety of chimneys and fireplaces, particularly on the advantages of different types of chimney construction blocks and liners, and on the conditions under which temperatures hazardous to combustible materials may develop on the outer surfaces of the structures.

Several types of chimney and flue liner arrangements, of varying degrees of suitability, are described in the papers. Brick chimney liners, or even better, chimneys having inner and outer shells of brick with mineral wool separation were reported as able to take the thermal shock of repeated hot fires of short duration [20, 22]. ${ }^{2}$ Ceramic flue liners were recommended by several investigators $[2,23,29]$ as these are reported to be subject to fewer cracks than brick linings or those constructions without linings. They were also found to give a lower temperature rise on the outer surface. There is indication of a definite advantage in having the inner lining free to move independently of the outer shell $[9,20,22,23]$ to minimize stresses arising from thermal differences and possible restraint of the outside wall. However, in one report [19] it is stated that a grouted liner is preferable because of its greater stability when cracked. Round flue liners are

\footnotetext{
2 Figures in hrackets indicate papers in the blbllography, Section 2, of this
} report. said to offer a reduction in stresses due to thermal effects, and to give better draft performance than those of other cross sections [2, 23].

Unlined chimneys, made of lightreight concrete (pumice or cinder aggregate), were reported as subject to the development of dangerous cracks which could allow the passage of hot gases or flame $[4,16]$. Some control of such cracking was reported possible by the use of horizontal reinforcing [2]. Concrete units having integrally cast liners developed cracks through both the liner and the masonry wall [23]. The resistance of concrete to heat and attack by flue gases is reported as lower than that of ceramic materials [2].

Concrete chimney block units may be successfully used if the aggregates have a low coefficient of expansion [2, 3], and the concrete is sufficiently aged [3]. Certain proprietary flue blocks, mainly with pozzuolanic aggregate, were found suitable [3-6]. The use of concrete flue blocks was reported as offering some technical and economic advantages [12].

Tests on prefabricated chimneys have indicated that units of double-wall metal pipe with $1 / 2$-in. airspace had the least heat transmission [8]. Porcelain-enameled metal chimneys (for solid or liquid fuel) when insulated with about $1 \frac{3 / 4}{4}$ in. of asbestos paper plies could meet the requirement of a limiting temperature rise of 375 degrees $\mathrm{F}$ 
on the outer surface when the flue gas temperature was $1000^{\circ} \mathrm{F}[30]$.

The conditions under which hazardous temperatures may develop on the outer surface of masonry chimneys are described in several reports $[7,9,26]$. Temperature data for the exterior face of a flue at various flue gas temperatures are given $[6,15]$. Temperatures reported as hazardous were also noted on fireplaces, particularly on back walls $[1,10]$. Tests have indicated the necessity for maintaining an air space between wood-framing members and a chimney $[7,9$, $26,28]$. Ignition of wood has occurred in some cases where a mineral wool filling was used in the 2-in. space between joists and chimney [23]. Temperatures described as hazardous were measured on the edges of floorboards or ceilings in contact with brick chimneys $[7,26]$, but staying of chimneys may be allowed by contact with flooring or roof sheathing not more than $13 / 2$ in. from the corners of a chimney [23]. On a standard masonry chimney, increasing the wall thickness by 4 in. where a wood girder was in contact, reduced temperature rise on the wood to acceptable limits [7].

Temperatures capable of igniting wood have been measured through a 4-in. brick base under the firebox of a stove directly on the floor, and by analogy this condition is applicable to fireplaces [28]. Thus, the practice current in some areas, of supporting a fireplace on a frame structure, could be hazardous.

It has been recommended that exposure of wood for long periods at elevated temperatures should be limited to a temperature rise of 90 degrees $F$ above room temperature $[8,24]$. These references also report that ignition temperatures of wood have been significantly lowered under continued exposure. It was noted that dried and scorched wood developed higher temperatures on the surface when exposed to heat than did new wood [25].

While the data available in the paper is pertinent to some of the problems of fire safety, the tests described were generally of limited scope and not applicable to all aspects of even a single problem. Differences in construction practices, fuels, and methods of heating further limit the usefulness of the reports.

Further work could be done on resolving certain contradictions in the information, especially in the fields of grouting of chimney liners and the effect of filling airspaces between heated surfaces and combustibles with mineral wool insulation. More knowledge also would be useful on the effect of prolonged exposure of wood on its ignition temperature. The hazards of chimneys and fireplaces could be further investigated to determine to what extent the formation of cracks through the structure is a source of danger. Finally, as it is the goal of much research, a study could be made leading to the development of new materials and products, for chimneys a permanent lightweight block not requiring a liner or additional insulation, and for fireplaces a substitute for the refractory lining.

Chimneys and fireplaces have been long used, but systematic investigations of fire safety, long left to chance and the saving feature of massive construction, have only recently been undertaken. Much remains to be done to gain the knowledge required to solve these problems in a manner consistent with assuring the best performance of the structures. 
NATIONAL BUREAU OF STANDARDS

A. V. Astin, Director

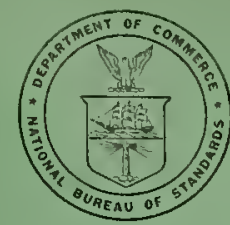

\section{THE NATIONAL BUREAU OF STANDARDS}

The scope of activities of the National Bureau of Standards at its major laboratories in Washington, D.C., and Boulder, Colorado, is suggested in the following listing of the divisions and sections engaged in technical work. ln general, each section carries out specialized research, development, and engineering in the field indicated by its title. A brief description of the activities, and of the resultant publications, appears on the inside of the front cover.

WASHINGTON, D. C.

Electricity. Resistance and Reactance. Electrochemistry. Electrical Instruments. Magnetic Measurements. Dielectrics. High Voltage. Absolute Electrical Measurements.

Metrology. Photometry and Colorimetry. Refractometry. Photographic Research. Length. Engineering Metrology. Mass and Volume.

Heat. Temperature Physics. Heat Measurements. Cryogenic Physics. Equation of State. Statistical Physics. Radiation Physics. X-ray. Radioactivity. Radiation Theory. High Energy Radiation. Radiological Equipment. Nucleonic Instrumentation. Neutron Physics.

Analytical and Inorganic Chemistry. Pure Substances. Spectrochemistry. Solution Chemistry. Standard Reference Materials. Applied Analytical Research. Crystal Chemistry.

Mechanics. Sound. Pressure and Vacuum. Fluid Mechanics. Engineering Mechanics. Rheology. Combustion Controls.

Polymers. Macromolecules: Synthesis and Structure. Polymer Chemistry. Polymez Physics. Polymer Characterization. Polymer Evaluation and Testing. Applied Polymer Standards and Research. Dental Research.

Metallurgy. Engineering Metallurgy. Metal Reactions. Metal Physics. Electrolysis and Metal Deposition. Inorganic Solids. Engineering Ceramics. Glass. Solid State Chemistry. Crystal Growth. Physical Properties. Crystallography.

Building Research. Structural Engineering. Fire Research. Mechanical Systems. Organic Building Materials. Codes and Safety Standards. Heat Transfer. Inorganic Building Materials. Metallic Building Materials.

Applied Mathematics. Numerical Analysis. Computation. Statistical Engineering. Mathematical Physics. Operations Research.

Data Processing Systems. Components and Techniques. Computer Technology. Measurements Automation. Engineering Applications. Systems Analysis.

Atomic Physics. Spectroscopy. Infrared Spectroscopy. Far Ultraviolet Physics. Solid State Physics. Electron Physics. Atomic Physics. Plasma Spectroscopy.

Instrumentation. Engineering Electronics. Electron Devices. Electronic Instrumentation. Mechanical Instruments. Basic lnstrumentation.

Physical Chemistry. Thermochemistry. Surface Chemistry. Organic Chemistry. Molecular Spectroscopy. Elementary Processes. Mass Spectrometry. Photochemistry and Radiation Chemistry.

Office of Weights and Measures.

BOULDER, COLO.

\section{CRYOGENIC ENGINEERING LABORATORY}

Cryogenic Processes. Cryogenic Properties of Solids. Cryogenic Technical Services. Properties of Cryogenic Fluids.

\section{CENTRAL RADIO PROPAGATION LABORATORY}

Ionosphere Research and Propagation. Low Frequency and Very Low Frequency Research. lonosphere Research. Prediction Services. Sun-Earth Relationships. Field Engineering. Radio Warning Services. Vertical Soundings Research.

Troposphere and Space Telecommunications. Data Reduction Instrumentation. Radio Noise. Tropospheric Measurements. Troposp:ieric Analysis. Spectrum Utilization Research. Radio-Meteorology. Lower Atmosphere Physics.

Radio Systems. Applied Electromagnetic Theory. High Frequency and Very High Frequency Research. Frequency Utilization. Modulation Research. Antenna Rescarch. Radiodetermination.

Upper Atmosphere and Space Physics. Upper Atmosphere and Plasma Physics. High Latitude lonosphere Physics. Ionosphere and Exosphere Scatter. Airglow and Aurora. lonospheric Radio Astronomy.

\section{RADIO STANDARDS LABORATORY}

Radio Standards Physics. Frequency and Time Disseminations. Radio and Microwave Materials. Atomic Frequency and Time-Interval Standards. Radio Plasma. Microwave Physics.

Radio Standards Engineering. High Frequency Electrical Standards. High Frequency Calibration Services. High Frequency Impedance Standards. Microwave Calibration Services. Microwave Circuit Standards. Low Frequency Calibration Services.

Joint Institute for Laboratory Astrophysics-NBS Group (Univ. of Colo.). 
